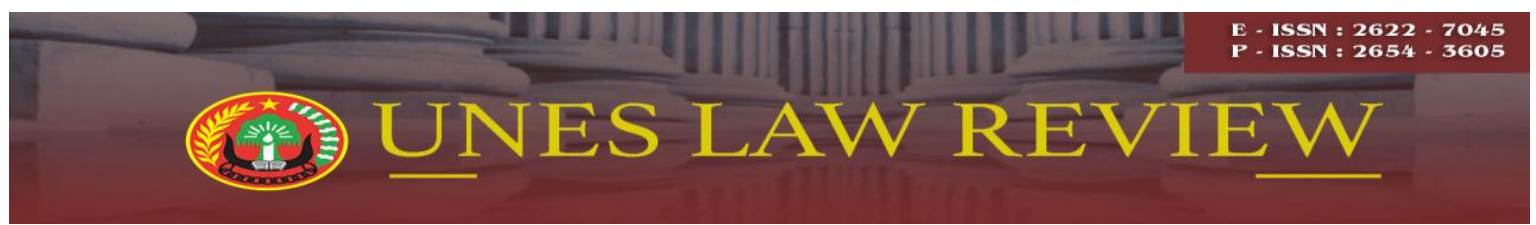

Email: uneslawreview@gmail.com

Online: http://review-unes.com/index.php/law

Volume 2, Issue 3, Maret 2020

\title{
PERLINDUNGAN HUKUM TERHADAP DEBITUR PADA PERJANJIAN PEMBIAYAAN KONSUMEN DENGAN PEMBEBANAN JAMINAN FIDUSIA
}

\author{
Subadra Yani \\ Yayasan Lembaga Konsumen Indonesia (YLKI), Lampung, Indonesia \\ Email: badmoerjane@yahoo.co.id
}

\begin{abstract}
Consumer financing is financing activities for the procurement of goods based on consumer needs with installment payments regulated in Article 1 number 7 of Presidential Regulation No. 9 of 2009 concerning Financing Institutions. To reduce losses if debtors default, the financing of motor vehicle consumers is charged with fiduciary guarantees regulated in Law Number 42 of 1999 concerning Fiduciary guarantees. In practice, the implementation of consumer financing for motor vehicles often results in problems that harm the debtor (consumer) especially when the acquisition of fiduciary collateral items if the debtor (consumer). therefore it is necessary to conduct research on how the legal protection of debtors in consumer financing agreements with the imposition of fiduciary guarantees. The data used are secondary supporting data collected through library studies and primary data as supporting data conducted through field studies using interview techniques. The results of the study found that: legal protection for debtors in consumer financing agreements with the imposition of fiduciary guarantees has been regulated in several relevant laws and regulations, namely the Consumer Protection Act, the Fiduciary Guarantee Act, the Financial Services Authority Act and the implementing regulations. If a consumer is harmed by a finance company, the debtor (consumer) can sue the finance company because of an unlawful act and may even ask for a criminal act.
\end{abstract}

Kata Kunci: Hukum, Perlindungan Hukum, Pembiayaan Konsumen, Fidusia

\section{PENDAHULUAN}

Pembiayaan konsumen adalah merupakan salah satu model pembiayaan yang dilakukan oleh perusahaan pembiayaan. Ketentuan hukum mengenai pembiayaan konsumen dan perusahaan pembiayaan ada di dalam Peraturan Presiden Nomor 9 Tahun 2009 tentang Lembaga Pembiayaan dan di dalam Peraturan Menteri Keuangan Nomor 84/PMK.012/2006 tentang Perusahaan Pembiayaan.

Pembiayaan konsumen merupakan perjanjian antara Perusahaan pembiayaan dan konsumen. Perusahaan pembiayaan menawarkan jasa pembiayaan kepada konsumen yang dapat diangsur, mudah dan cepat, bunga yang terjangkau, waktu yang fleksibel dan 
berbagai penawaran yang menarik, sehingga konsumen dapat tergiur oleh iming-iming yang memudahkan mendapatkan barang tanpa memikirkan kekuatan finansialnya. Perjanjian dalam pembiayaan konsumen ini bersifat baku/standar, dimana isi dari klausulaklausula perjanjian sudah ditentukan oleh perusahaan pembiayaan. Selain mendapatkan manfaat yang tidak sedikit pembelian barang melalui jasa pembiayaan konsumen, juga menghasilkan kemungkinan beberapa risiko yang terjadi, baik bagi debitur (konsumen) maupun kreditur (perusahaan pembiayaan)

Risiko yang dihadapi perusahaan pembiayaan dalam pembiayaan konsumen adalah risiko gagal bayar atau konsumen melakukan wanprestasi tidak membayar angsuran sesuai waktu yang sudah ditetapkan atau konsumen yang melakukan kecurangan yang sering terjadi pada pembiayaan kendaran bermotor, seperti penggelapan atau penggunaan kendaran untuk melakukan perbuatan pidana. Untuk mengatasi risiko, terjadi gagal bayar oleh konsumen, perusahaan pembiayaan menerapkan adanya jaminan pada pembiayaan konsumen. Walaupun pada tataran teori kegiatan pembiayaan konsumen tidak menekankan pada aspek jaminan (Hartono dan Hadisoeprapto, 2001:50) (collateral), seperti pada lembaga keuangan bank. Jaminan yang diterapkan perusahaan pembiayaan meliputi jaminan utama berupa kepercayaan dan jaminan tambahan berupa promes, kuasa menjual perusahaan pembiayaan juga mensyaratkan adanya jaminan pokok berupa barang-barang yang menjadi objek perjanjian (Sunaryo, 2008:112).

Lembaga Jaminan Fidusia diakui eksistensinya dengan terbitnya UU Nomor 42 tahun 1999 tentang Jaminan Fidusia, yang telah diundangkan pada tanggal 30 September 1999. Sebagaimana diketahui bahwa Jaminan Fidusia adalah hak agunan/jaminan atas benda bergerak yang berwujud maupun tidak berwujud, atau yang tidak dapat dibebani hak tanggungan menurut Undang-Undang Nomor 4 Tahun 1996 tentang Hak Tanggungan, yang dimiliki oleh Penerima Fidusia yang terdaftar di Kantor Pendaftaran Fidusia, yaitu sebagai agunan bagi pelunasan utang tertentu dan yang mempunyai hak untuk didahulukan dari pada para kreditur lainnya.

Sedangkan risiko yang dihadapi konsumen pengguna jasa perusahaan pembiayaan (finance), yaitu perjanjian yang bersifat baku atau standar dimana semua ketentuan dan syarat-syarat perjanjian dibuat sepihak oleh perusahaan pembiayaan, yang sering banyak memberatkan konsumen. Adanya denda harian yang diberikan. perusahaan pembiayaan 
kepada nasabahnya yang tidak membayar tepat pada waktunya. Denda tersebut terus diakumulasi sampai konsumen membayar angsuran berikut dendanya. Risiko yang selanjutnya adalah penyitaan barang yang dijadikan objek pembiayaan konsumen dengan dibebankan jaminan fidusia apabila terjadi gagal bayar oleh debitur. Risiko yang ini yang sering terjadi dalam prakteknya di masyarakat, dimana perusahaan pembiayaan langsung melakukan penarikan atas kendaran bermotor yang di bebankan jaminan fidusia.

Dalam hal ini debitur dalam posisi yang lemah, karena ketidaktahuannya bahwa ada kewajiban hukum yang harus dilakukan perusahaan pembiayaan pada saat terjadinya perjanjian pembiayaan konsumen untuk mendaftarkan objek jaminan fidusia pada kantor pendaftaran fidusia, sebagaimana tersebut dalam Pasal 11 UU Jaminan Fidusia, yang berbunyi :

(1) Benda yang dibebani jaminan fidusia wajib didaftarkan;

(2) Dalam hal benda yang dibebani dengan jaminan fidusia berada di luar wilayah Negara Republik Indonesia, kewajiban sebagaimana dimaksud dalam ayat (1) tetap berlaku.

Khusus perusahan pembiayaan konsumen untuk kendaran bermtor kewajiban hukum tersebut terdapat dalam Pasal 1 ayat (1) Peraturan Menteri Keuangan Nomor 130/PMK.010/2012 tentang Pendaftaran Jaminan Fidusia Bagi Perusahaan Pembiayaan Yang Melakukan Pembiayaan Konsumen Untuk Kendaraan Bermotor Dengan Pembebanan Jaminan Fidusia, yang berbunyi :

Perusahaan pembiayaan yang melakukan pembiayaan konsumen untuk kendaraan bermotor dengan pembebanan jaminan fidusia wajib mendaftarkan jaminan fidusia dimaksud pada kantor pendaftaran fidusia, sesuai undang-undang yang mengatur mengenai jaminan fidusia.

Kewajiban hukum tersebut harus dilakukan paling lama 30 (tiga puluh) hari sejak tanggal perjanjian pembiyaan konsumen, sebagaimana tersebut dalam Pasal 2 Peraturan Menteri tersebut, yang berbunyi :

Perusahaan pembiayaan wajib mendaftarkan jaminan fidusia pada kantor Pendaftaran Fidusia paling lama 30 (tiga puluh) hari kalender terhitung sejak tanggal perjanjian pembiayaan konsumen.

Apabila perusahaan pembiayaan tidak melakukan kewajiban tersebut, maka perusahaan pembiayaan tidak memiliki hak eksekutorial atas kendaran bermotor yang dibebankan jaminan fidusia. Hal ini berarti perusahaan pembiayaan dilarang untuk 
melakukan penarikan/penyitaan terhadap kendaran bermotor yang dijadikan objek jaminan fidusia, sebagaimana tersebut dalam Pasal 3 dari Peraturan Menteri tersebut, yang berbunyi:

Perusahaan pembiayaan dilarang melakukan penarikan benda jaminan fidusia berupa kendaran bermotor apabila kantor pendaftaran fidusia belum menerbitkan sertifikat jaminan fidusia dan menyerahkan kepada perusahaan pembiayaan.

Dalam praktek perusahaan pembiayaan seringkali lalai dalam melakukan pendaftaran tersebut, namun apabila terjadi gagal bayar perusahaan pembiayaan walaupun tidak memiliki hak eksekutorial tetap melakukan penarikan atas kendaraan bermotor yang dibebankan jaminan fidusia tersebut. Hal ini tentu sangat merugikan pihak debitur. Berdasarkan isi-isu hukum di atas, maka perlu dilakukan penelitian tentang :

1. Bagaimanakah Perlindungan Hukum Terhadap Debitur Pada Perjanjian Pembiayaan Konsumen Dengan Pembebanan Jaminan Fidusia?

2. Bagaimanakah pelaksanaan eksekusi barang jaminan fidusia oleh perusahaan pembiayaan jika terjadi wanprestasi debitur dalam kaitannya dengan pemenuhan hak-hak para pihak?

\section{METODE PENELITIAN}

Penelitian ini merupakan penelitian deskriptif. Pendekatan yang digunakan dalam penelitian ini adalah pendekatan yuridis normatif, yakni dengan mempelajari dan mengkaji asas-asas hukum khususnya kaidah-kaidah hukum positif yang berasal dari bahan-bahan kepustakaan yang ada dari peraturan perundang-undangan serta ketentuan-ketentuan terutama tentang pembiayaan konsumen dan jaminan fidusia. Di dukung dengan pendekatan yuridis empiris, yaitu penelitian untuk melihat bekerjanya hukum dalam prakteknya di masyarakat mengenai perlindungan hukum terhadap debitur dalam perjanjian pembiayaan konsumen dengan pembebanan jaminan fidusia (Soerjono Soekanto, 2001:4).

Data yang digunakan dalam penelitian ini mencakup data sekunder dan data primer. Teknik pengumpulan data sekunder yang mencakup bahan hukum primer, sekunder dan tersier dilakukan dengan cara studi kepustakaan. Teknik pengumpulan data primer dilakukan melalui studi lapangan dengan teknik wawancara semi struktur kepada para pihak yang terkait dalam penelitian ini, yaitu : 
1. Kepala Bidang Pelayanan Hukum Kanwil Hukum dan HAM Propinsi Lampung.

2. Kepala Otoritas Jasa Keuangan Provinsi Lampung.

3. Kepala Kantor FIF Bandar Lampung.

\section{HASIL PENELITIAN DAN PEMBAHASAN}

\section{Perlindungan Hukum Terhadap Debitur Dalam Perjanjian Pembiayaan Konsumen Dengan Pembebanan Jaminan Fidusia.}

Perjanjian pembiayaan konsumen merupakan pengembangan dari hukum perjanjian di luar Kitab Undang-Undang Hukum Perdata (KUHPerdata). Perjanjian pembiayaan konsumen pada umumnya perjanjian dibuat dalam suatu kontrak baku. Klausula-klausula dalam perjanjian tersebut sudah dibuat secara sepihak oleh perusahaan pembiayaan, konsumen hanya bisa memilih untuk sepakat atau tidak terhadap perjanjian tersebut. Kondisi ini menyebabkan lemahnya posisi konsumen sebagai debitur bila dibandingkan dengan pihak perusahaan pembiayaan konsumen sebagai kreditur, karena ketika perjanjian sudah ditandatangani, maka asumsinya konsumen telah bersedia memikul beban dan tanggung jawab sebagimana tercantum dalam perjanjian baku tersebut.

Dalam perjanjian pembiayaan konsumen, pihak pemberi dana (perusahaan pembiayaan konsumen) sebagai kreditur dan pihak penerima dana (konsumen) sebagai pihak debitur. Pihak Perusahaan pembiayaan konsumen berkewajiban utama memberikan sejumlah uang untuk pembelian suatu barang-barang kebutuhan konsumen, sedangkan pihak penerima biaya (konsumen) berkewajiban utama untuk membayar kembali uang tersebut secara cicilan kepada pemberi biaya.

Pemberian kredit (utang) oleh perusahaan pembiayaan (kreditur) kepada konsumen (debitur) harus didasarkan pada kepercayaan kreditur bahwa debitur mampu untuk melunasi dan membayar kreditnya. Begitu pula sebaliknya, debitur dalam memilih krediturnya tentu memperhatikan apakah kreditur merupakan badan usaha yang prudence, memiliki legalitas, dan conduct (perilaku usaha) yang baik dengan menjadi konsumen yang cerdas melalui aktif mengumpulkan informasi dan menanyakan legalitas Lembaga pembiayaan tersebut. Pemberian kepercayaan ini menjadi dasar dalam penyebutan pinjaman dari seorang kreditor kepada seorang debitur sebagai kredit (credit) yang berasal dari kata credere yang berarti kepercayaan atau trust. 
Untuk meningkatkan keyakinan kreditur terhadap debitur, kreditur harus melaksanakan prinsip Know Your Costumer (KYC) yang dapat diterapkan dengan sistem analisis prinsip 5C kepada nasabah yang terdiri dari character (karakter nasabah), capital (modal nasabah), capacity (kemampuan nasabah), collateral (agunan), and condition of economy (kondisi ekonomi nasabah). Pemberian collateral (agunan) oleh debitur merupakan salah satu bentuk perlindungan dengan melakukan pengikatan dengan pembebanan jaminan terhadap utang debitur kepada kreditur, untuk lebih memantapkan keyakinan kreditur bahwa debitur membayar utangnya. Atas fasilitas kredit yang diberikan oleh perusahaan pembiayaan dilakukan

Salah satu bentuk penjaminan yang digunakan oleh perusahaan pembiayaan adalah Jaminan Fidusia, yang diatur dalam UU Nomor 42 Tahun 1999 tentang Jaminan Fidusia. Berdasarkan Pasal 1 ayat (1) dan (2) UUJF, dijelaskan bahwa, fidusia dibedakan dari jaminan fidusia. Fidusia merupakan suatu proses pengalihan hak kepemilikan, dan jaminan fidusia adalah jaminan yang diberikan dalam bentuk fidusia (Gunawan Widjaja dan Ahmad Yani, 2000,123). Jaminan Fidusia merupakan penyerahan hak milik secara kepercayaan atau fiduciary transfer of ownership, karena penyerahan hak milik ini tidak disertai dengan penyerahan objek dari jaminan fidusia. sehingga yang diserahkan kepada penerima fidusia (kreditur) adalah bukti hak miliki kebendaan tersebut. misalnya seperti BPKP, bukti tagih hutang, dan lainnya.

Fidusia umumnya dimasukkan dalam perjanjian kredit kendaraan bermotor atau benda bergerak lainnya serta bangunan yang tidak dapat dibebankan dengan Hak Tanggungan. Menurut Pasal 27 ayat (2) UUJF, Pembebanan jaminan fidusia atas suatu benda memberikan hak kepada kreditur selaku penerima fidusia untuk mengambil pelunasan terlebih dahulu atas piutangnya kepada debitur pemberi jaminan fidusia (droit de preferren/hak preferen). Karena hak preferen dimiliki oleh kreditur, maka apabila debitur/ pemberi fidusia cidera janji, debitur wajib menyerahkan benda yang dijadikan objek fidusia dalam rangka pelaksanaan eksekusi jaminan fidusia.

Keterlambatan pembayaran cicilan kendaraan bermotor pada perjanjian pembiayaan konsumen merupakan bentuk wanprestasi debitur (konsumen). Akibat wanprestasi tersebut, maka debitur (konsumen) wajib menyerahkan kendaraan bermotornya sebagai objek jaminan fidusia kepada kreditur (perusahaan pembiayaan) 
untuk kemudian dilakukan eksekusi berupa penjualan motor dalam rangka pelunasan utang kepada perusahaan.

Dalam praktek perjanjian pembiyaan konsumen sering menimbulkan masalah, dalam hal ini posisi konsumen adalah paling lemah dan dirugikan di bandingkan dengan posisi perusahaan pembiayaan. Hal terlihat dalam setiap perjanjian pembiayaan konsumen dengan pembebanan jaminan fidusia untuk kendaran bermotor, konsumen tidak diberikan fotocopy dan/atau salinan sertifikat jaminan fidusia sehingga konsumen tidak mengetahui ada tidaknya hak eksekutorial bagi perusahaan pembiayaan untuk melakukan penarikan paksa kendaran bermotor sebagai barang jaminan apabila konsumen tidak dapat memenuhi kewajiban untuk membayar angsuran. Hal ini yang seringkali menimbulkan sengketa konsumen dan berakhir pada adanya tindak pidana seperti : penganiayaan, dan perbuatan tidak menyenangkan. Dalam hak eksekusi barang jaminan konsumen juga tidak diberitahu mengenai hasil pelelangan barang jaminan tersebut. Oleh karena itu diperlukan suatu perlindungan hukum kepada konsumen.

Menurut Satjipto Rahardjo dalam Abdul Atsar (2007:298) perlindungan hukum adalah melindungi kepentingan seseorang dengan cara mengalokasikan suatu kekuasaan. Perlindungan hukum yang diberikan adalah bentuk kepentingan bersama dalam upaya pembangunan nasional (Muhammad Syiblunnur, 2017:5). Peran pemerintah adalah menjamin adanya penegakan hukum demi tercapainya keadilan (Muhamad Solichin, 2018:5). Transaksi pembiayaan konsumen dilakukan tidak hanya berdasarkan kehendak para pihak saja, yaitu antara perusahaan pembiayaan konsumen dan konsumen yang dituangkan dalam perjanjian, tetapi juga diatur oleh beberapa peraturan perundangan yang bersifat publik administratif, yang merupakan wujud perlindungan yang diberikan pemerintah dan memberikan kepastian hukum

Pemerintah telah menerbitkan UU Nomor 42 Tahun 1999 tentang Jaminan Fidusia. Undang-undang ini berlaku untuk semua perjanjian yang bertujuan untuk membebani benda dengan jaminan fidusia. Salah satu bentuk penjaminan yang digunakan oleh perusahaan pembiayaan konsumen adalah jaminan fidusia, oleh karena itu perusahaan pembiayaan wajib mematuhi ketentuan UUJF, dimana kendaraan bermotor yang dijadikan benda jaminan fidusia wajib didaftarkan kepada kantor pendaftaran fidusia. Hal ini sesuai 
dengan ketentuan Pasal 11 ayat (1) UUJF yang menyebutkan bahwa : "benda yang dibebani dengan jaminan fidusia wajib didaftarkan".

Jaminan Fidusia lahir pada saat diterbitkannya sertifikat jaminan fidusia. Kewajiban pendaftaran ini paling lama 30 (tiga puluh) hari kalender terhitung sejak tanggal perjanjian pembiayaan konsumen, sesuai ketentuan Pasal 2 Peraturan Menteri Keuangan Nomor 130/PMK.010/2012 tentang Pendaftaran Fidusia Bagi Perusahaan Pembiayaan, yang berbunyi :

Perusahaan pembiayaan wajib mendaftarkan jaminan fidusia pada kantor pendaftaran fidusia paling lambat 30 (tiga puluh) hari kalender terhitung sejak tanggal perjanjian pembiayaan konsumen.

Kewajiban pendaftaran Jaminan Fidusia ini merupakan perwujudan dari asas publisitas dan kepastian hukum baik bagi kreditor dan debitor. Saat ini pendaftaran Jaminan Fidusia telah dilakukan secara online sebagaimana yang diatur dalam Peraturan Kementerian Hukum dan HAM Nomor 9 Tahun 2013 tentang Pemberlakuan Pendaftaran Jaminan Fidusia secara Elektronik. Pemberlakukan pendaftaran secara online ini dimaksudkan untuk mempermudah dan menghemat waktu.

Perjanjian fidusia merupakan perjanjian ikutan dari perjanjian pokoknya. Perjanjian fidusia pada perjanjian pembiayaan konsumen, maka yang menjadi perjanjian pokoknya adalah utang-piutang dalam bentuk pembiayaan, dimana para pihaknya adalah kreditur (perusahaan pembiayaan) dan debitur adalah konsumen. Jika ada benda yang dijadikan jaminan fidusia, maka harus dibuat dengan akta notaris, dalam akta jaminan fidusia sekurang-kurangnya harus memuat:

1. Identitas pihak pemberi dan penerima fidusia;

2. Data perjanjian pokok yang dijamin fidusia;

3. Uraian mengenai benda yang menjadi objek jaminan fidusia;

4. Nilai penjaminan; dan

5. Nilai benda yang menjadi objek jaminan fidusia.

Walaupun UUJF tidak mengatur tentang keharusan para pihak untuk hadir pada saat membuat akta jaminan fidusia. Tetapi jika ditelusuri, pada prinsipnya perjanjian yang dibuat di hadapan notaris akan menjadi suatu alat bukti yang kuat di kemudian hari dalam hal terjadi sengketa perdata, hal itu tercantum dalam Pasal 1902 ayat (2) Kitab UndangUndang Hukum Perdata ("KUH Perdata"), yang berbunyi: 
Yang dinamakan bukti permulaan tertulis ialah segala akta tertulis yang berasal dari orang yang terhadapnya suatu tuntutan diajukan atau dari orang yang diwakili olehnya dan yang kiranya membenarkan adanya peristiwa hukum yang diajukan oleh seseorang sebagai dasar tuntutan itu.

Sehingga dapat diketahui pentingnya sifat dari kehadiran para pihak dalam pembuatan akta tersebut, karena sangat penting untuk pembuktian di kemudian hari jika terjadi permasalahan hukum. Dengan kehadiran para pihak dalam pembuatan akta jamina fidusia tersebut dapat memperkuat pembuktiannya (untuk membenarkan telah terjadi suatu peristiwa hukum) jika suatu hari terjadi permasalahan hukum di pengadilan. Walaupun pembuatan akta jaminan fidusia dapat diwakilkan dalam hal biasanya hanya diwakilkan oleh perusahaan pembiayaan, namun dalam hal ini menurut Pasal 1792 KUHPerdata pihak yang berkepentingan dalam hal ini debitur (pemberi kuasa) memberikan kuasa dalam bentuk tertulis kepada penerima kuasa untuk pembuatan jaminan fidusia.

Apabila debitur wanprestasi atau tidak dapat memenuhi kewajiban untuk membayar angsuran menurut Pasal 15 ayat (3) UUJF penerima fidusia mempunyai hak untuk menjual benda yang menjadi obyek jaminan fidusia atas kekuasaannya sendiri. Eksekusi terhadap objek jaminan fidusia dapat dilakukan dengan cara yang terdapat dalam Pasal 29 ayat (1) UUJF, yaitu:

1. Pelaksanaan titel eksekutorial sebagaimana dimaksud dalam pasal 15 ayat (2) oleh Penerima Fidusia;

2. Penjualan Benda yang menjadi obyek Jaminan Fidusia atas kekuasaan penerima fidusia sendiri melalui pelelangan umum serta mengambil pelunasan piutangnya dari hasil penjualan;

3. Penjualan di bawah tangan yang dilakukan berdasarkan kesepakatan Pemberi dan Penerima Fidusia jika dengan cara demikian dapat diperoleh harga tertinggi yang menguntungkan para pihak.

Walaupun UUJF telah memberikan hak kepada perusahaan pembiayaan untuk menjual barang jaminan, namun hak tersebut hanya diberikan kepada perusahaan pembiayaan yang sudah menerima sertifikat fidusia dari kantor pendaftaran fidusia, karena lahirnya perjanjian fidusia adalah pada saat diterbitkannya sertifikat jaminan fidusia. Penarikan tersebut juga harus sudah disepakati oleh para pihak dalam perjanjian pembiayaan konsumen. Oleh karena bagi perusahaan pembiayaan yang tidak memiliki sertifikat jaminan fidusia dilarang melakukan penarikan benda jaminan fidusia sesuai 
dengan ketentuan Pasal 3 Peraturan Menteri Keuangan Nomor 130/PMK.010/2012 tentang Pendaftaran Fidusia Bagi Perusahaan Pembiayaan :

Perusahaan pembiayaan dilarang melakukan penarikan benda jaminan fidusia berupa kendaraan bermotor apabila kantor pendaftaran fidusia belum menerbitkan sertifikat jaminan fidusia dan menyerahkannya kepada perusahaan pembiayaan.

Apabila perusahaan pembiayaan melanggar ketentuan tersebut, maka menurut ketentuan Pasal 5 Peraturan Menteri Keuangan Nomor 130/PMK.010/2012 dapat dikenai sanksi secara bertahap berupa :

1. Peringatan;

2. Pembekuan kegiatan usaha;

3. Pencabutan izin usaha.

Selain itu dalam melakukan penarikan barang jaminan fidusia, perusahaan pembiayaan juga harus tunduk dan taat pada ketentuan OJK yang dituangkan dalam Peraturan Otoritas Jasa Keuangan Republik Indonesia Nomor 35/POJK.05/2018 tentang Penyelenggaraan Usaha Pembiayaan. Peraturan tersebut secara tegas mengatur perusahaan pembiayaan dalam melakukan penagihan dan melakukan eksekusi objek jaminan fidusia apabila debitur telah wanprestasi. Dalam melakukan penarikan barang jaminan fidusia, POJK tersebut memberikan kewenangan kepada perusahaan pembiayaan untuk bekerjasama dengan pihak lain dalam melaksanakan fungsi penagihan, dengan persyaratan bahwa pihak lain tersebut berbentuk badan hukum, memiliki izin dari instansi berwenang dan pihak lain tersebut memiliki sumber daya manusia yang telah memperoleh sertifikasi di bidang penagihan dan harus dibuat dalam bentuk tertulis, sebagaimana tersebut dalam Pasal 48 POJK Nomor 35/POJK.05/2018, yang berbunyi :

1. Perusahaan pembiayaan dapat melakukan kerjasama dengan pihak lain untuk melakukan fungsi penagihan kepada debitur.

2. Perusahaan pembiayaan wajib menuangkan kerjasamadengan pihak lain sebagaiamana dimaksud pada ayat (1) dalam bentuk perjanjian tertulis bermaterai;

3. Kerjasama dengan pihak lain sebagaimana dimaksus pada ayat (1) wajib memenuhi ketentuan sebagai berikut :

a. Pihak lain tersebut berbentuk badan hukum;

b. Pihak lain tersebut memiliki izin dari instansi yang berwenang; dan

c. Pihak lain tersebut memiliki sumber daya manusia yang telah memperoleh sertifikat di bidang penagihan dari Lembaga Sertifikasi Profesi di bidang pembiayaan.

4. Perusahaan pembiayaan bertanggungjawab penuh atas segala dampak yang ditimbulkandari kerjasama dengan pihak lain sebagaimana dimaksud pada ayat (1); 
5. Perusahaan pembiayaan wajib melakukan evaluasi secara berkala atas kerjasama dengan pihak lain sebagaimana dimaksud pada ayat (1).

Perusahaan pembiayaan yang melibatkan orang ketiga (debt collector) yang tidak sesuai dengan ketentuan dalam Pasal 48 POJK Nomor 35/POJK.05/2018 pada saat melakukan penarikan kendaraan bermotor yang diikat jaminan fidusia apabila debitur wanprestasi, maka dapat dikenai sanksi administrasi secara bertahap sesuai ketentuan Pasal 115 POJK Nomor 35/POJK.05/2018, berupa :

1. Peringatan;

2. Pembekuan kegiatan usaha; dan

3. Pencabutan izin usaha

Selain sanksi administrasi Otoritas Jasa keuangan juga dapat :

1. Melakukan pembatasan kegiatan usaha tertentu;

2. Menurunkan hasil penilaian tingkat risiko;

3. Melakukan pembatalan persetujuan, dan/atau

4. Melakukan penilaian kembali kemampuan dan kepatutan kepada pihak utama perusahaan pembiayaan

Penarikan kendaraan bermotor yang dibebankan jaminan fidusia oleh pihak perusahaan pembiayaan apabila debitur wanprestasi tanpa membawa sertifikat jaminan fidusia dan melibatkan pihak debt collector dengan merampas secara paksa, dapat dikenakan sanksi sesuai ketentuan Pasal 115 POJK 35/POJK.05/2018 dan dikatagorikan perbuatan melawan hukum atau perbuatan pidana, yang dapat dijerat dengan Pasal 1365 KUHPerdata tentang Perbuatan Melawan Hukum atau tindak pidana pemaksaan dan ancaman perampasan sebagaimana diatur Pasal 365 KUHPidana.

Pelaksanaan parate eksekusi terhadap objek jaminan fidusia tidak dapat dilakukan secara serta merta, melainkan kreditur harus terlebih dahulu membuktikan bahwa debitur telah wanprestasi, debitur sudah diberikan surat peringatan, perusahaan pembiayaan memiliki sertifikat jaminan fidusia yang wajib didaftarkannya 1 (bulan) sejak tanggal perjanjian pembiayaan. Jika eksekusi tersebut berhasil dilakukan maka kreditur wajib menuangkannya ke dalam berita acara eksekusi agunan yang menjelaskan kepada debitur mengenai, outstanding pokok, bunga terutang, denda terutang, biaya terkait eksekusi dan mekanisme penjualan objek jaminan fidusia tersebut jika debitur tidak dapat memenuhi kewajibannya. Apabila debitur tidak mau melaksanakan parate eksekusi, langkah hukum 
yang dapat dilakukan kreditur adalah dengan mengajukan permohonan kepada pengadilan agar menetapkan aanmaning, lalu permohonan penetapan sita eksekusi dan selanjutnya permohonan lelang eksekusi terhadap objek jaminan fidusia berdasarkan sertifikat jaminan fidusia yang telah didaftarkan sebelumnya.

Penjualan terhadap barang jaminan fidusia dapat dilakukan melalui pelelangan umum atau penjualan di bawah tangan. Jika penjualan angguan melalui pelelangan umum, maka harus diumumkan di surat khabar paling lambat enam hari sebelumnya lelang dilakukan sesuai ketentuan Peraturan Menteri Keuangan Nomor 27/PMK.06/2016 tentang Petunjuk Pelaksanaan Lelang. Apabila penjualan di bawah tangan harus dilakukan berdasarkan kesepakatan harga perusahaan pembiayaan dan debitur sebelum objek jaminan fidusia di jual. Pelaksanaan penjualan tersebut harus dilakukan setelah lewat waktu 1(satu) bulan sejak pemberitahuan tertulis oleh perusahaan pembiayaan kepada debitur, dan diumumkan paling sedikit dalam 2 (dua) surat kabar di daerah tersebut.

Setelah penjualan barang jaminan melalui pelelangan umum atau penjualan di bawah tangan, debitur (konsumen) memiliki hak-hak yang tercantum dalam Pasal 4 Undang-Undang Nomor 8 Tahun 1999 tentang Perlindungan Konsumen, yaitu : "hak untuk mendapatkan informasi yang benar, jelaskan dan jujur dan hak untuk diperlakukan atau dilayani secara benar dan jujur serta tidak diskriminatif mengenai sisa kelebihan hasil penjualan barang jaminan. Kreditur memiliki kewajiban yang diatur dalam Pasal 7 UUPK, yaitu kreditur harus beritikad baik dalam menjalankan usahanya dan memberikan informasi secara benar dan memperlakukan konsumen secara benar dan jujur mengembalikan kelebihan sisa hasil penjualan tersebut kepada debitur (Konsumen) dalam jangka waktu sesuai dengan perjanjian pembiayaan. Setelah utang konsumen dilunasi, maka perusahaan pembiayaan juga wajib mengajukan penghapusan jaminan fidusia terhadap objek yang dijaminkan. Penghapusan jaminan fidusia merupakan bagian yang penting untuk melindungi konsumen, karena apabila tidak dilakukan penghapusan pada daftar jaminan fidusia maka konsumen tidak dapat mempergunakan objek tersebut sebagai objek jaminan fidusia untuk perjanjian utang selanjutnya atau dianggap melakukan fidusia ulang yang dilarang oleh UUJF.

Berdasarkan uraian di atas, maka dapat disimpulkan bahwa perlindungan hukum terhadap konsumen pada perjanjian pembiayaan konsumen dengan pembebanan jaminan 
fidusia yang terdapat dalam KUHPerdata, UUPK, UUJF dan POJK dan peraturan pelaksanaannya dapat dilihat pada tabel berikut :

Tabel 1

Perlindungan Hukum Terhadap Konsumen Pada Perjanjian Pembiayaan Konsumen dengan Pembebanan Jaminan Fidusia dalam KUHPerdata, UUPK, UUJF, Permenkeu dan POJK

\begin{tabular}{|c|c|c|c|}
\hline KUH & $\begin{array}{c}\text { UUJF dan } \\
\text { Peraturan Menteri } \\
\text { Keuangan } \\
\text { 30/PMK.010/2012 }\end{array}$ & POJK N & \\
\hline $\begin{array}{l}\text { Pasal } 1365 \\
\text { tentang } \\
\text { Perbuatan } \\
\text { Melawan } \\
\text { Hukum. } \\
\text { Penarikan } \\
\text { benda yang } \\
\text { dijadikan } \\
\text { jaminan } \\
\text { fidusia oleh } \\
\text { pihak } \\
\text { perusahaan } \\
\text { apabila } \\
\text { debitur } \\
\text { wanprestasi } \\
\text { jika dilakukan } \\
\text { tanpa } \\
\text { membawa } \\
\text { sertifikat } \\
\text { jaminan } \\
\text { fidusia dan } \\
\text { melibatkan } \\
\text { pihak debt } \\
\text { collector } \\
\text { dengan } \\
\text { merampas } \\
\text { secara paksa, } \\
\text { dapat } \\
\text { dikatagorikan } \\
\text { perbuatan } \\
\text { melawan } \\
\text { hukum. } \\
\text { Melanggar }\end{array}$ & $\begin{array}{l}\text { Pasal 11 UUJF } \\
\text { Perusahaan } \\
\text { pembiayaan wajib } \\
\text { mendaftarkan benda } \\
\text { yang dijadikan } \\
\text { jaminan fidusia } \\
\text { kepada Kantor } \\
\text { Pendaftaran } \\
\text { Pasal 2 Peraturan } \\
\text { Menteri Keuangan } \\
\text { 130/PMK.010/ } \\
\text { 2012 ini } \\
\text { Kewajiban } \\
\text { pendaftaran } \\
\text { harus dilakukan } \\
\text { paling lambat } 30 \\
\text { hari sejak tanggal } \\
\text { perjanjian } \\
\text { pembiayaan } \\
\text { konsumen. } \\
\text { Pasal 3 Peraturan } \\
\text { Menteri Keuangan } \\
\text { Nomor } \\
\text { 130/PMK.010/ } \\
\text { 2012 a didusia } \\
\text { Perusahaan } \\
\text { pembiayaan } \\
\text { larang melakukan } \\
\text { penarik an benda } \\
\text { jaminan apabila } \\
\text { berupa kendaraan } \\
\text { bermotor andar } \\
\text { kantor pendaftaran } \\
\text { fidusia belum } \\
\text { menerbitkan }\end{array}$ & $\begin{array}{l}\text { Pasal } 48 \text { POJK Nomor } \\
\text { 35/POJK.05/2018 } \\
\text { Perusahaan pembiaya an dapat } \\
\text { melakukan kerjasama dengan } \\
\text { pihak lain untuk me-lakukan } \\
\text { fungsi penagihan kepada debitur. } \\
\text { Perusahaan pembiaya an wajib } \\
\text { menuangkan kerjasamadengan } \\
\text { pihak lain sebagaia mana } \\
\text { dimaksud pada ayat (1) dalam } \\
\text { bentuk perjanjian tertulis } \\
\text { bermaterai; dengan pihak lain } \\
\text { Kerjasama dena } \\
\text { sebagai-mana dimaksud pada } \\
\text { ayat (1) wajib memenuhi } \\
\text { ketentuan sebagai berikut : } \\
\text { Pihak lain tersebut berbentuk } \\
\text { badan hukum; } \\
\text { Pihak lain tersebut memiliki izin } \\
\text { dari instansi yang berwenang; } \\
\text { dan lan } \\
\text { Pihak lain tersebut memiliki } \\
\text { sumber daya manusia yang telah } \\
\text { memperoleh sertifikat di bidang } \\
\text { penagihan dari Lem-baga } \\
\text { Sertifikasi Pro-fesi di bidang } \\
\text { pem-biayaan. } \\
\text { Perusahaan pembiaya an } \\
\text { bertanggungjawab penuh atas } \\
\text { segala dampak yang ditim- } \\
\text { bulkan dari kerjasama dengan } \\
\text { pihak lain sebagaimana dimak- } \\
\text { sud pada ayat (1); } \\
\text { Pasal 115 POJK Nomor }\end{array}$ & $\begin{array}{l}\text { Pasal } 4 \text { UUPK } \\
\text { Hak untuk } \\
\text { mendapat kan } \\
\text { informasi yang } \\
\text { benar, jelaskan } \\
\text { dan jujur dan } \\
\text { hak untuk } \\
\text { diperlakukan } \\
\text { atau dilayani } \\
\text { secara benar } \\
\text { dan jujur serta } \\
\text { tidak } \\
\text { diskriminatif } \\
\text { mengenai sisa } \\
\text { kelebihan hasil } \\
\text { penjualan } \\
\text { barang jaminan. } \\
\text { Pasal } 7 \text { UUPK } \\
\text { Kreditur } \\
\text { (perusahaan } \\
\text { pembiayaan) } \\
\text { harus beritikad } \\
\text { baik dalam } \\
\text { menjalankan } \\
\text { usahanya dan } \\
\text { memberikan } \\
\text { informasi } \\
\text { secara benar } \\
\text { dan menar } \\
\text { memperlakukan } \\
\text { konsumen secara benar } \\
\text { dan jujur } \\
\text { mengembalikan } \\
\text { kelebihan sisa }\end{array}$ \\
\hline
\end{tabular}




\begin{tabular}{|c|c|c|c|}
\hline KUHPerdata. & $\begin{array}{l}\text { sertifikat jaminan } \\
\text { fidusia dan } \\
\text { menyerahkannya ke } \\
\text { pada perusahaan } \\
\text { pembiaya an. } \\
\text { Pasal 5 Peraturan } \\
\text { Menteri Keuangan } \\
\text { Nomor } \\
\text { 130/PMK.010/2012 } \\
\text { perusahaan } \\
\text { pembiayaan } \\
\text { melanggar } \\
\text { ketentuan dapat } \\
\text { dikenai } \\
\text { secara sanksi } \\
\text { berupa : } \\
\text { Peringatan; } \\
\text { Pembekuan } \\
\text { kegiatan usaha; } \\
\text { 3. Pencabutan izin } \\
\text { usaha. }\end{array}$ & $\begin{array}{l}\text { 35/POJK.05/ } 2018 \\
\text { Perusahaan pembiayaan yang } \\
\text { melibatkan orang ketiga (debt } \\
\text { collector) yang tidak sesuai } \\
\text { dengan ketentuan dalam Pasal } 48 \\
\text { POJK Nomor 35/POJK.05/2018 } \\
\text { pada saat melakukan penarik an } \\
\text { kendaraan bermotor yang diikat } \\
\text { jaminan fidusia apabila debitur } \\
\text { wanprestasi, maka dapat dikenai } \\
\text { sanksi administrasi secara } \\
\text { bertahap, berupa: } \\
\text { Peringatan; } \\
\text { Pembekuan kegiatan usaha; dan } \\
\text { Pencabutan izin usaha } \\
\text { Selain sanksi adminis-trasi } \\
\text { Otoritas Jasa keuangan juga } \\
\text { dapat: } \\
\text { Melakukan pembatasan kegiatan } \\
\text { usaha ter-tentu; } \\
\text { Menurunkan hasil penilaian } \\
\text { tingkat risiko; } \\
\text { Melakukan pembatalan } \\
\text { persetujuan, dan/atau } \\
\text { Melakukan penilaian kembali } \\
\text { kemampuan dan kepatutan ke- } \\
\text { pada pihak utama perusahaan } \\
\text { pem-biayaan }\end{array}$ & $\begin{array}{l}\text { hasil penjualan } \\
\text { tersebut kepada } \\
\text { debitur } \\
\text { (Konsumen) } \\
\text { dalam jangka } \\
\text { waktu sesuai } \\
\text { dengan } \\
\text { perjanjian } \\
\text { pembiayaan. }\end{array}$ \\
\hline
\end{tabular}

\section{Pelaksanaan Eksekusi Terhadap Barang Jaminan Fidusia Oleh Perusahaan Pembiayaan Dalam Kaitannya Dengan pemenuhan Hak-Hak para pihak}

Perjanjian pembiayaan konsumen merupakan perjanjian pokok, sedangkan perjanjian jaminan fidusia adalah perjanjian ikutan. Apabila kredit yang diberikan perusahaan pembiayaan kepada debitur (konsumen) sudah dilunasi, maka perjanjian jaminan fidusia menjadi hapus. Namun apabila debitur wanprestasi atau tidak melaksanakan kewajibannya untuk melunasi cicilan kredit, maka menjadi hak kreditur 
(perusahaan pembiayaan) untuk melakukan eksekusi terhadap benda yang menjadi objek jaminan fidusia (kendaraan bermotor).

Dalam melaksanakan eksekusi barang jaminan fidusia dalam transaksi pembiayaan konsumen, perusahaan pembiayaan harus berpedoman kepada ketentuan peraturan perundang-undangan terkait di antaranya adalah Undang-Undang Nomor 42 Tahun 1999 tentang Jaminan Fidusia dan Peraturan Otoritas Jasa Keuangan Republik Indonesia Nomor 35 /Pojk.05/2018 tentang Penyelenggaraan Usaha Perusahaan Pembiayaan.

Perusahaan pembiayaan hanya boleh melakukan ekeskusi terhadap jaminan fidusia apabila apabila perusahaan pembiayaan memiliki sertifikat jaminan fidusia serta debitur benar-benar telah melakukan wanprestasi dan sudah diberikan surat peringatan, sebagaimana diatur dalam Pasal 50 Peraturan Otoritas Jasa Keuangan Republik Indonesia Nomor 35 /Pojk.05/2018 tentang Penyelenggaraan Usaha Perusahaan Pembiayaan, yang berbunyi :

Eksekusi agunan oleh Perusahaan Pembiayaan wajib memenuhi ketentuan sebagai berikut:

1. Debitur terbukti wanprestasi;

2. Debitur sudah diberikan surat peringatan; dan

3. Perusahaan Pembiayaan memiliki sertifikat jaminan fidusia, sertifikat hak tanggungan, dan/atau sertifikat hipotek.

Terhadap pelaksanaan eksekusi objek jaminan fidusia perusahaan pembiayaan hanya dapat melakukannya sesuai dengan cara-cara sebagaimana tersebut dalam Pasal 29 UUJF, yaitu :

1. Apabila debitur atau pemberi fidusia cedera janji, eksekusi terhadap benda yang menjadi objek jaminan fidusia dapat dilakukan dengan cara :

a. Pelaksanaan titel eksekutorial sebagaimana dimaksud dalam Pasal 15 ayat (2) oleh penerima fidusia;

b. Penjualan benda yang menjadi objek jaminan fidusia atas kekuasaan penerima fidusia sendiri melalui pelelangan umum serta mengambil pelunasan piutang dari hasil penjualan;

c. Penjualan di bawah tangan yang dilakukan berdasarkan kesepakatan pemberi dan penerima fidusia, jika dengan cara demikian dapat diperoleh harga tertinggi yang menguntungkan para pihak.

2. Pelaksanaan penjualan sebagaimana dimaksud dalam ayat (1) huruf c dilakukan setelah lewat waktu 1 (satu) bulan sejak diberitahukan secara tertulis oleh Pemberi dan Penerima Fidusia kepada pihak-pibak yang berkepentingan dan diumumkan sedikitnya dalam 2 (dua) surat kabar yang beredar di daerah yang bersangkutan. 
Ketiga cara eksekusi Jaminan Fidusia tersebut di atas masing-masing memiliki perbedaan dalam prosedur pelaksanaannya. Berbeda dengan penjualan dibawah tangan pelaksanaanya harus memenuhi beberapa persyaratan antara lain adanya kesepakatan antara konsumen (debitur) dan lembaga pembiayaan (kreditur). Alasanya untuk memperoleh nilai penjualan yang lebih baik untuk memperoleh harga tertinggi (Netty SR Naiborhu, 2006:164).

Apabila eksekusi terhadap benda jaminan dilakukan melalui pelelangan umum, maka menurut ketentuan Pasal 29 ayat (1) UUJF, metode lelang melalui parate eksekusi berdasarkan titel eksekutorial yang terdapat dalam sertifikat jaminan fidusia. Eksekusi dilakukan tanpa perintah eksekusi dari ketua pengadilan negeri (fiat eksekusi). Pemegang fidusia, dalam hal ini perusahaan pembiayaan, menjual obyek fidusia melalui pelelangan umum, dengan pengajuan permohonan tertulis perihal eksekusi kepada Kepala Kantor Pelayanan Kekayaan Negara dan Lelang (KPKNL)/Balai Lelang Swasta. Hasil pelelangan digunakan untuk pelunasan utang.

Apabila eksekusi terhadap benda jaminan dilakukan dengan cara penjualan di bawah tangan atas dasar kesepakatan pemberi dan penerima fidusia menurut Pasal 29 ayat (2) UUJF harus dilakukan setelah lewat waktu 1 (satu) bulan sejak diberitahukan secara tertulis oleh pemberi dan penerima fidusia kepada pihak-pihak yang berkepentingan dan diumumkan paling sedikit dalam 2 (dua) surat khabar yang beredar di daerah yang bersangkutan.

Perusahaan pembiayaan dalam melaksanakan ekeskusi objek jaminan fidusia, wajib menuangkannya dalam berita acara eksekusi agunan dan wajib memberikan informasi kepada debitur (konsumen) mengenai outstanding utang, bunga terutang, denda biaya eksekusi dan mekanisme penjualan sebagaimana tersebut dalam Pasal 50 ayat (3) dan (4) Peraturan Otoritas Jasa Keuangan Republik Indonesia Nomor 35 /Pojk.05/2018 tentang Penyelenggaraan Usaha Perusahaan Pembiayaan, yang berbunyi :

(3) Eksekusi agunan sebagaimana dimaksud pada ayat (1) wajib dituangkan dalam berita acara eksekusi agunan.

(4) Dalam hal terjadi eksekusi agunan, Perusahaan Pembiayaan wajib menjelaskan kepada Debitur informasi mengenai:
a. Outstanding pokok terutang;
b. Bunga yang terutang;
c. Denda yang terutang; 
d. Biaya terkait eksekusi agunan; dan

e. Mekanisme penjualan agunan dalam hal Debitur tidak menyelesaikan kewajibannya.

Hasil penjualan objek jaminan fidusia digunakan untuk menutup sisa utang debitur, bunga dan denda serta biaya-biaya lain, apabila terdapat sisa dari hasil penjualan ini menjadi kewajiban bagi kreditur untuk mengembalikannya kepada debitur (Konsumen) yang merupakan haknya, sesuai ketentuan Pasal 52 Peraturan Otoritas Jasa Keuangan Republik Indonesia Nomor 35/Pojk.05/2018 tentang Penyelenggaraan Usaha Perusahaan Pembiayaan, yang berbunyi :

Perusahaan Pembiayaan wajib mengembalikan uang kelebihan dari hasil penjualan agunan melalui pelelangan umum sebagaimana dimaksud dalam Pasal 51 ayat (1) huruf a atau penjualan agunan di bawah tangan sebagaimana dimaksud dalam Pasal 51 ayat (1) huruf b kepada Debitur dalam jangka waktu sesuai dengan perjanjian pembiayaan.

Berdasarkan hasil penelitian PT. FIF dalam menyelesaikan perjanjian pembiayaan kendaraan bermotor yang bermasalah dalam hal debitur wanprestasi atau tidak dapat melunasi hutangnya adalah dilakukan penarikan terlebih dahulu terhadap objek jaminan fidusia yaitu kendaraan bermotor. Perusahaan melakukan penjualan terhadap barang jaminan untuk kemudian hasil penjualan akan dipergunakan untuk menutupi sisa hutang penerima fasilitas sesuai dengan kalkulasi yang sudah disepakati. Dalam penjualan barang jaminan tersebut, penjualan dilakukan dengan cara mengumpulkan kendaraan bermotor yang tidak dilunasi oleh debitor pada gudang internal milik perusahaan tersebut, kemudian dilakukan pelelangan atau penjualan kepada dealer mobil bekas yang sudah bekerja sama dengannya. Kendaraaan tersebut dapat dijaminkan lagi sebagai jaminan kebendaan pada perjanjian pembiayaan konsumen perusahaan yang baru.

Perusahaan melakukan penyitaan ini dapat disamakan dengan parate eksekusi dengan alasan bahwa dengan eksekusi langsung berdasarkan parate eksekusi seperti lebih sederhana dibandingkan dengan proses melalui pengadilan. Relatif efektif dan efisien dalam waktu dan biaya karena bisa dilakukan secara kekeluargaan tanpa mengunakan tenaga pengacara dan dokumen yang dipersiapkan tidak harus bermacam-macam. Pihak perusahaan telah melakukan tindakan preventif dengan melampirkan surat kuasa untuk melakukan penarikan kendaran bermotor yang ditandatangani oleh debitur sendiri, 
perjanjian pemberian fidusia dan perjanjian pembiayaan konsumen yang kesemuanya merupakan bukti yang mengikat bagi kedua belah pihak dan memuat perihal penarikan hingga penjualan dimuka umum yang telah ditandatangani oleh debitur sendiri.

Lebih lanjut dalam melaksanakan penjualan setelah dilakukan penarikan jaminan yang semulanya di bawah penguasaan debitor. Adapun penjualan yang dipilih menurut pihak perusahaan yaitu penjualan di muka umum atau lelang. Demi terjaganya perputaran modal di dalam perusahaan, keputusan tersebut dinilai cukup tepat karena dengan media lelang diharapkan menguntungkan bagi kreditor serta tidak memakan waktu yang lama dalam pengembalian piutangnya. Oleh kreditor digunakan istilah penjualan di muka umum atau lelang dalam pengertian yang khusus yaitu lelang untuk kalangan terbatas dimana peserta lelangnya hanya untuk kalangan dealer/supplier yang merupakan mitra bisnis kreditor.

Pelelangan dilakukan berdasarkan persyaratan yang ditentukan oleh pihak kreditor sendiri. Kreditor sebagai penjual dan peserta lelang adalah dealer/supplier. Dealer/supplier sebagai peserta lelang yang keluar sebagai pemenang lelang adalah pembeli yang sah. Adapun proses pelaksanaan lelang, lelang dilakukan terhadap kendaraan bermotor yang dijaminkan dan telah berada dalam penguasaaan kreditor dan telah lampaunya tenggang waktu bagi debitor untuk melaksanakan itikad baiknya maka secara otomatis objek jaminan tersebut dilakukan penjualan secara lelang. Sebelum melakukan pelelangan maka pihak perusahaan melakukan pengumuman melalui surat pemberitahuan dan sekaligus mengundang para rekanan bisnis yaitu para dealer/supplier. Dipilihnya dealer/supplier karena alasan bahwa mereka memiliki usaha yang bergerak di bidang pembelian penjualan kendaraan bermotor baik yang masih baru atau bekas yang telah menjalin hubungan bisnis yang cukup baik dengan pihak kreditor selaku perusahaan penyedia untuk pembeliaan barang jaminan fidusia.

Terhadap pelaksanaan eksekusi barang jaminan fidusia dalam prakteknya berdasarkan hasil penelitian dan observasi peneliti bahwa sering terjadi tidak adanya transaparansi dari perusahaan pembiayaan terhadap debitur (konsumen). Berdasarkan hasil penelitian banyaknya pengaduan konsumen kepada YLKI dan Lembaga OJK terkait dengan eksekusi jaminan fidusia dan perilaku debt collector dalam melakukan penarikan kendaraan Jaminan Fidusia. Walaupun sudah ada pengaturannya di dalam UUJF dan 
Peraturan OJK (POJK), perusahaan pembiayaan sering tidak memberitahukan kepada konsumen tentang hasil penjualan barang jaminan fidusia dan tidak mengembalikan sisa hasil penjualan barang jaminan fidusia tersebut kepada debitur (konsumen) yang menjadi haknya. Dalam hal ini menurut pendapat penulis bahwa perusahaan pembiayaan tidak melaksanakan asas itikad baik (te goeder trouw/in good faith) yang diatur Pasal 1320 ayat (3) KUHPerdata bahwa semua perjanjian harus dilaksanakan dengan itikad. Asas ini menegaskan bahwa para pihak dalam membuat perjanjian harus didasarkan pada itikad baik dan kepatutan, yang mengandung pengertian pembuatan perjanjian antara para pihak harus didasarkan pada kejujuran untuk mencapai tujuan bersama.

Pelaksanaan perjanjian juga harus mengacu pada apa yang patut dan seharusnya diikuti dalam pergaulan masyarakat. Asas ini merupakan asas yang harus ada dalam setiap perjanjian, dan tidak bisa ditiadakan meskipun para pihak menyepakatinya (immutable) (Ery Agus Priyono, 2017). Asas itikad baik mengandung pengertian suatu keadaan batin para pihak dalam membuat dan melaksanakan perjanjian harus jujur, terbuka dan saling percaya. Keadaan batin para pihak itu tidak boleh dicemari oleh maksud-maksud untuk melakukan tipu daya atau menutup-nutupi keadaan sebenarnya. Iktikad baik dalam hukum Romawi mengacu kepada 3 (tiga) bentuk perilaku para pihak dalam kontrak (Mohammad Syaifuddin, 2012:95):

1. Para pihak harus memegang teguh janji atau perkatannya.

2. Para pihak tidak boleh mengambil keuntungan dengan tindakan yang menyesatkan terhadap salah satu pihak.

3. Para pihak mematuhi kewajibannya dan berperilaku sebagai orang terhormat dan jujur walaupun kewajiban itu tidak secara tegas diperjanjikan.

Selain itu menurut pendapat penulis terkait eksekusi barang jaminan oleh perusahaan pembiayaan juga terjadi perbuatan tidak menyenangkan atas perbuatan debt collector mengambil secara paksa kendaraan debitur di jalanan. Istilah debt-collector berasal dari bahasa Inggris yaitu debt dan collector. Debt berarti hutang dan collector berarti pengumpul. Debt Collector dianggap mencerminkan kriteria penagihan yang mengutamakan tindakan kekerasan dan dianggap tidak pantas digunakan pada perusahaan leasing di Indonesia. Istilah lain dari debt collector ini adalah agency penagih. Agency penagih adalah pihak ketiga yang menghubungkan antara kreditur dengan debitur dalam hal penagihan hutang kredit. 
Debt-collector merupakan pihak ketiga, yang memiliki perjanjian dengan perusahaan leasing untuk melakukan upaya pemaksaan pengambilan kendaraan debitur karena belum membayar angsuran sebagaimana yang telah disepakati. Debt-collector sering dianggap oleh masyarakat sebagai penagih yang menggunakan kekerasan, sehingga mau tidak mau debitur harus menyerahkan kendaraan yang masih dalam cicilan tersebut kepada perusahaan leasing selama debitur belum melunasi angsurannya.

Menurut Pasal 1 PMK No.130/PMK.010/2012, perusahaan pembiayaan (leasing) yang melakukan pembiayaan konsumen untuk kendaraan bermotor dengan pembebanan jaminan fidusia wajib mendaftarkan jaminan dimaksud pada kantor pendaftaran fidusia sesuai dengan undang-undang yang mengatur mengenai jaminan fidusia. UUJF memberikan jaminan kepada debitur dan kreditur (leasing) dalam proses eksekusi atau penarikan kendaraan yang mengalami kredit macet. Tanpa adanya sertifikat fidusia, debtcollector tidak boleh melakukan eksekusi di jalan karena berpotensi menimbulkan pelanggaran pidana. Namun, faktanya tidak sedikit perusahaan leasing yang tidak mendaftarkan objek.

\section{PENUTUP}

\section{Kesimpulan}

Berdasarkan hasil penelitian dan analisis yang telah diuraikan dalam bab-bab sebelumnya, maka disimpulkan hal-hal sebagai berikut :

1. Perlindungan hukum terhadap debitur dalam perjanjian pembiayaan konsumen dengan pembebanan jaminan fidusia adalah : sudah diatur dibeberapa peraturan perundangundangan terkait, yaitu Pasal 1365 KUHPerdata tentang Perbuatan Melanggar Hukum apabila kreditur dalam menarik barang jaminan tanpa memperlihatkan sertifikat fidusia, Pasal 11 UUJF tentang kewajiban mendaftarkan benda yang dijadikan jaminan fidusia ke kantor Pendaftaran, Pasal 2 Permenkeu Nomor 130/PMK.010/2012 mengenai kewajiban mendaftarkan jaminan fidusia dalam waktu 30 hari sejak tanggal perjanjian pembiayaan dilakukan dan POJK Nomor 35/POJK.05/2018 mengenai persyaratan melibatkan pihak ketiga dalam penarikan barang jaminan fidusia apabila debitur wanprestasi. Apabila konsumen dirugikan oleh perusahaan pembiayaan, maka debitur (konsumen) dapat menggugat perusahaan pembiayaan konsumen karena perbuatan melawan hukum, bahkan dapat menututnya karena perbuatan pidana.

2. Pelaksanaan eksekusi barang jaminan fidusia oleh perusahaan pembiayaan jika terjadi wanprestasi debitur dalam kaitannya dengan pemenuhan hak-hak para pihak adalah dapat dilakukan dengan cara : a) Pelaksanaan titel eksekutorial oleh penerima fidusia; b) Penjualan benda yang menjadi objek jaminan fidusia atas kekuasaan penerima fidusia 
sendiri melalui pelelangan umum serta mengambil pelunasan piutang dari hasil penjualan; c) Penjualan di bawah tangan yang dilakukan berdasarkan kesepakatan pemberi dan penerima fidusia, jika dengan cara demikian dapat diperoleh harga tertinggi yang menguntungkan para pihak. Hasil penjualan objek jaminan fidusia digunakan untuk menutup sisa utang debitur, bunga dan denda serta biaya-biaya lain yang menjadi hak kredit, sisa hasil penjualan menjadi hak debitur (Konsumen) yang harus dikembalikan oleh kreditur.

\section{Saran-Saran}

1. Perusahaan pembiayaan dalam praktek memberikan pembiayaan kepada konsumen dengan sistem angsuran, hendaknya mengikuti aturan perundang-undangan yang berlaku, baik UUPK, UUJF, POJK dan aturan yang terkait lainnya, sehingga masingmasing pihak mendapatkan hak dan menunaikan kewajibannya.

2. Apabila terjadi wanprestasi, maka hak eksekutorial yang dimiliki oleh lembaga pembiayaan seharusnya tidak dilaksanakan secara serta merta tanpa mempertimbangkan keseimbangan, keadilan, hak dan kewajiban konsumen.

\section{DAFTAR PUSTAKA}

\section{Buku Taks:}

Gunawan Widjaja dan Ahmad Yani, Jaminan Fidusia, Raja Grafindo Persada, Jakarta, 2000

Hartono dan Hadisoeprapto, Pokok-Pokok Hukum Perikatan dan Hukum Jaminan, Liberty, Yogyakarta, 2001.

Mohammad Syaifuddin, Hukum Kontrak, Memahami Kontrak dalam Perspektif Filsafat, teori, Dokmatik dan praktek Hukum, Bandung, Mandar Maju, 2012.

Soerjono Soekanto, Penelitian Hukum Normatif Suatu Tinjauan Singkat, PT. Raja Grafindo Persada Jakarta, 2001.

Sunaryo, Hukum Lembaga Pembiayaan, Sinar Grafika, Jakarta, 2008.

\section{Hasil Penelitian \& Journal:}

Abdul Atsar, Perlindungan Hukum terhadap Pengetahuan dan Ekspresi Budaya Tradisional untuk Meningkatkan Kesejahteraan Masyarakat ditinjau dari Undang-Undang No. 5 Tahun 2017 tentang Pemajuan Kebudayaan dan Undang-Undang No. 28 Tahun 2014 tentang Hak Cipta”, Jurnal Law Reform, Volume 13, Nomor 2, , "Fakultas Hukum Universitas Diponegoro, 2007

Bagir Manan, Penelitian di Bidang Hukum, Jumal Pusat Penelitian Perkembangan Hukum No. 1, UNPAD, Bandung, 1999.

Ery Agus Priyono, Peranan Asas Itikad Baik Dalam Kontrak Baku (Upaya Menjaga Keseimbangan bagi Para Pihak), Artikel dalam Diponegoro Private Law Review• Vol. 1 No. 1 November 2017. 
Muhamad Solichin, Politik Hukum Praperadilan dalam Penegakan Hukum". Naskah Publikasi (Tesis). Universitas Muhammadiyah Surakarta, Surakarta, 2018.

Muhammad Syiblunnur, Perlindungan Hukum Pada Pelayanan Kesehatan Tingkat Pertama Di Kabupaten Kotawaringin Timur, (Tesis), Universitas Muhammadiyah Surakarta, Surakarta, 2017.

Netty SR Naiborhu, Pelaksanaan Eksekusi Jaminan Berdasarkan Parate Eksekusi oleh Kreditur, Jurnal wawasan Hukum, 2006.

\section{Peraturan Perundang-Undangan:}

Kitab Undang-undang Hukum Perdata;

Undang-Undang Nomor 8 Tahun 1999 tentang Perlindungan Konsumen;

Undang-Undang Nomor 42 Tahun 1999 tentang Jaminan Fidusia;

Undang-Undang Nomor 21 Tahun 2011 tentang Otoritas Jasa Keuangan;

Peraturan Pemerintah Nomor 9 Tahun 2009 tentang Lembaga Pembiayaan;

Peraturan Pemerintah Nomor 86 Tahun 2000 tentang Tata Cara Pendaftaran Jaminan Fidusia dan Biaya Pembuatan Akta Jaminan Fidusia

Peraturan Menteri Keuangan Nomor 84/PMK.012/2006 tentang Perusahaan Pembiayaan.

Peraturan Menteri Keuangan Nomor 130/PMK.010/2012 tentang Pendaftaran Jaminan Fidusia Bagi Perusahaan Pembiayaan Yang Melakukan Pembiayaan Konsumen Untuk Kendaraan Bermotor Dengan Pembebanan Jaminan Fidusia;

Peraturan Menteri Keuangan Nomor 43/Pmk.010/2012 tentang Uang Muka Pembiayaan Konsumen Untuk Kendaraan Bermotor Pada Perusahaan Pembiayaan;

Peraturan Menteri Keuangan Nomor 27/PMK.06/2016 tentang Petunjuk Pelaksanaan Lelang.

Peraturan Kementerian Hukum dan HAM Nomor 9 Tahun 2013 tentang Pemberlakuan Pendaftaran Jaminan Fidusia secara Elektronik.

Keputusan Menteri Keuangan Nomor 185/Kmkm.06/2002 Tahun 2002 tentang Penghentian Pemberian Izin Usaha Perusahaan Pembiayaan;

Peraturan Otoritas Jasa Keuangan Republik Indonesia Nomor 35 /Pojk.05/2018 tentang Penyelenggaraan Usaha Perusahaan Pembiayaan 